\title{
ANALISIS PENGARUH RASIO KEUANGAN TERHADAP HARGA SAHAM PADA PERUSAHAAN INDUSTRI BARANG KONSUMSI YANG TERDAFTAR DI BEI
}

Melisa Yuana ${ }^{1}$, Taudlikhul Afkar ${ }^{2}$

Universitas PGRI Adi Buana Surabaya ${ }^{1,2}$

melisayuana83@gmail.com, afkarloveyoufull@gmail.com

\begin{abstract}
The purpose for this study to analyze also study the presence or absence of financial ratios that contribut to stock prices. The population in this study is the financial statements of consumer goods industry companies that are listed on the IDX. The study used 36 samples from 6 consumer goods companies with a reporting period of 6 years. Secondary data is a type of data in this study. The method or method used is the quantitative method, where data are analyzed with the classic assumption test, multiple linear regression, also the coefficient of determination. The research carried out resulted in a significant variable influencing the share price of ROA and EPS. Whereas $C R, D E R$, and TATO had no significant effect on stock prices.

Keywords: Financial Ratios, Stock Prices.
\end{abstract}

\section{PENDAHULUAN}

Harga saham merupakan harga yang ada di sebuah saham sebagai satu kategori yang dapat dijadikan acuan berhasilnya perusahaan dari pada yang lainnya. Perusahaan yang berhasil mengelola keuangannya maupun kinerjanya dengan baik maka harga sahamnya dapat tinggi. Tapi, jika ada perusahaan yang harga sahamnya rendah, bisa juga karena kinerjanya belum bagus.

Harga saham dapat berubah. Berubahnya bisa disebabkan karena perusahaan mengalami penurunan keuangan juga pengelolaan yang lain belum maksimal. Sehingga perusahaan harus dapat menjaga kinerjanya dengan baik agar harga sahamnya tidak turun.

Pasar modal merupakan tempat orang yang jual dan yang beli dana ketemu untuk melakukan transaksi . Transaksi dilakukan seperti membeli dana dalam bentuk saham yang dapat dipakai untuk beberapa tahun kedepan. Hal ini bisa digunakan dalam upaya membuat perusahaan tambah berkembang. Ada banyak perusahaan industri di Indonesia, salah satunya adalah perusahaan industri barang konsumsi.

Rasio keuangan merupakan suatu kegiatan angka- angka dibagi dengan angka- angka yang lain di laporan keuangan. Angka- angka itu bisa dibagi untuk mengukur tingkat kesuksesan perusahaan. Sehingga orang yang akan menilai dapat tau kesuksesan perusahaan dari rasio tersebut. Kasmir (2013:110) Rasio Keuangan dikelompokkan menjadi lima seperti rasio likuiditas, solvabilitas, aktivitas, profitabilitas dan pasar.

Rasio keuangan CR, DER dan PER dapat berpengaruh terhadap harga saham (Astuti, 2017). Pada penelitian (Nurcahyo, 2016) juga menyatakan bahwa ada beberapa rasio yang mempunyai pengaruh dengan harga saham.

NPM dan ROE juga dapat mempengaruhi tinggi rendahnya harga sahm (Saputra, 2011). Rendahnya harga saham dapat disebabkan rendah juga kinerja pada perusahaannya.

Dari pendapat yang disampaikan beberapa peneliti sebelumnya, dapat di gunakan menjadi dasar, tidak semua rasio keuangan itu ada pengaruh dengan harga saham. Karena itulah penting untuk membuktikannya.

Pembuktian yang akan dilakukan harus sesuai teori yang dapat mendukung. Tidak boleh asal asalan pembuktian tanpa ada pendukung atau teori yang dijadikan pedoman secara jelas. Alasan saya memakai perusahaan ini dalam penelitian karena industri konsumsi merupakan industri yang ada di BEl, memiliki kemampuan memperlihatkan kondisi saham di pasaran secara jelas dan juga nyata dari pada industri lain. Selain itu, juga sangat memberi keuntungan yang banyak bagi jalannya ekonomi di Indonesia. Pajak yang diberikan juga cukup tinggi. Sehingga menjadi industri yang 


\section{Journal of Sustainability Business Research (JSBR) \\ Vol-1,Issue-1,Desember (JSBR) \\ E-ISSN: 2746-8607 \\ http://jurnal.unipasby.ac.id/index.php/jsbr}

berkembang. Kemudian, munculnya lapangan kerja yang banyak dan luas dari perusahaan konsumsi untuk masyarakat.

\section{TINJAUAN PUSTAKA DAN HIPOTESIS \\ LANDASAN TEORI}

Tindakan yang dipilih perusahaan pada pemberian petunjuk dan arah bagi investor dalam mencari tahu prospek kerja suatu perusahaan disebut dengan tori sinyal. Dengan adanya teori ini, investor dapat informasi tentang pengelolaan perusahaan melalui manajemen. Informasi itu sangat berguna untuk bisa digunakan oleh pihak yang butuh akan sesuuatu yang ada di perusahaan.

Jika suatu perusahaan yang sudah bisa mengedarkan saham, tetapi tidak bisa memberikan sinyal informasi kepada para calon pembeli saham, maka yang akan beli sahamnya bisa sangat sedikit karena kurangnya mendapat informasi saham yang diedarkan. Sebaliknya, informasi yang dikasih secara baik kepada pihak luar guna membeli saham, akan membuat saham semakin di cari oleh orang yang ingin mempunyai saham.

Informasi merupakan suatu yang penting memberikan penjelasan mengenai hal yang ada. Apalagi perusahaan. Tentunya membutuhkan informasi dari luar atau dalam , untuk kelangsungan kegiatan yang ada. Kedua informasi tersebut memiliki peran yang sama - sama pentingnya.

Kasmir (2010), mendefinisikan investasi sebagai tanam atas dana untuk jangka waktu yang lama guna segala macam kegiatan yang bisa menguntungkan. Sedangkan, Hartono (2010:5) ialah pemakaian dana sekarang yang dibatalkan untuk dipakai di waktu yang lain dalam rangka penggunaan dana di saat yang tepat juga mendapat keuntungan atas dana itu..

Investasi ini dilakukan untuk mengurangi pemakaian dana yang dimiliki secara cepat pada saat sekarang, melainkan menggunakan dana dengan baik supaya memperoleh keuntungan di hari yang lain. Dengan adanya kegiatan ini, orang yang mempunyai dana banyak, dapat menggunakannya untuk hal yang bermanfaat, tidak secara boros. Karena , merupakan kegiatan yang menguntungkan untuk dijadikan sebagai penghasilan dari pada dijadikan sebagi pengeluaran.

Maghfiroh (2018) pasar modal menyediakan sekuritas modal yang dapat dijual dan dibeli oleh orang untuk kepentingan investor. Sekuritas yang dapat dijual dan dibeli merupakan milik perusahaan yang sudah besar. Harganya juga beragam, termasuk jenis sekuritasnya juga banyak macamnya.

Surat yang sangat berharga sebagai tanda seseorang memiliki sebuah perusahaan disebut sebagai saham. Berharga disini artinya sangat penting. Penting untuk dijaga, dimiliki dengan baik dan dipergunakan sebagai mana perlunya. Orang dikatakan memiliki perusahaan karena ada saham atas namanya. Perusahaan yang mempunyai saham berarti telah berhasil mengelola aktivanya sehingga dimilki banyak orang.

Saham antara perusahaan satu dengan lain berbeda. Bisa beda dari nilainya, jenisnya ataupun beda tingkat kerugiannya ataupun keuntungannya. Orang yang memiliki saham, harus merasa siap atas kejadian selama perusahaan yang dimiliki berjalan. Entah itu bisa kejadian yang membuat untung atau kejadian yang membuat rugi.

Astuti (2017) Rasio keuangan terdiri atas dua angka atau lebih terdapat pada Iporan keuangan yang dihubungkan menjadi satu untuk dihitung. Nisa (2015) rasio keuangan sebagai alat yang bisa membagi dan menghubungkan perkiraan yang ada pada laporan keuangan untuk menampilkan kondisi keuangan perusahaan.

Nisa (2018), CR didefinisikan sebagai perhitungan kesanggupan bisa tidaknya perusahaan melunasi hutang dalam waktu pendek. Jika dapat melunasi hutang dalam jangka pendek maka dapat dipastikan bahwa kinerjanya sudah cukup bagus. Apabila tidak bisa melunasi dengan jangka pendek, maka kinerja nya kurang maksimal.

Widayanti dan Colline ( 2017), untuk tahu banyaknya hutang yang dilunasi dengan pembiayaan modal maka bisa menggunakan rasio yang disebut DER. Hutang yang dilunasi lewat pembiayaan modal secara terus terusan akan menimbulkan terancamnya perusahaan terhadap terjadinya rugi besar-besaran / pembangkrutan. 


\section{Journal of Sustainability Business Research (JSBR) \\ Vol-1,Issue-1,Desember (JSBR) \\ E-ISSN: 2746-8607 \\ http://jurnal.unipasby.ac.id/index.php/jsbr}

Nisa (2018), TATO merupakan rasio yang bisa menjumlah semua total penjualan dari masing masing aktiva. Barang yang dijual kepada konsumen dapat dikatakn sebagai asset yang dimiliki perusahaan. Atas hasil penjualan inilah dapat dibandingkan denga banyaknya asset yang dimilkinya, bertambah keuntungankah atau bertambah kerugian. Sedangkan EPS ialah rasio untuk menentukan keuntungan dari setiap lembar saham yang telah beredar. Laba pada setiap lembar saham tentunya harus sama. Begitu juga ketika perusahaan mengalami kerugian, maka juga harus ditanggung secara sama porsinya. Ini sudah menjadi hal yang pasti pada orang yang mempunyai surat berharga saham sebagai tanda memiliki perusahaan.

Saputra (2011), ROE dapat digunakan untuk mengetahui serta menghitung keuntungan bersih yang diperoleh perusahaan setelah dikurangkan dengan bunga maupun pajak. Jika keuntungan yang diperoleh belum dkiurangkan dengan bunga atau pajak yang ada, maka keuntungan tersebut belum bisa dikatakan sebagai keuntungan bersihnya.

\section{KERANGKA KONSEPTUAL}

Dengan dibuatnya kerangka ini, agar bisa tau hubungan antara variabel bebas dan variabel terikat. Kerangka konseptual penelitian dapat dilihat dari gambar :

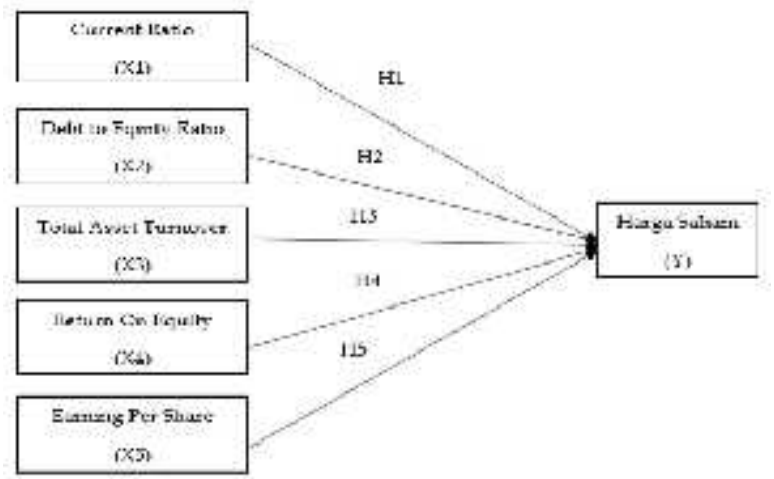

Gambar 1. Kerangka Konseptual

Dari gambar tersebut, saya bisa membuat beberapa jawaban sementara untuk diuji. Hipotesis yang dapat disusun oleh peneliti :

\footnotetext{
* Ada pengaruh positf CR terhadap harga saham(H1)

* Ada pengaruh positif DER terhadap harga saham(H2)

* Ada pengaruh positif TATO terhadap harga saham(H3)

* Ada pengaruh positif ROE terhadap harga saham(H4)

* Ada pengaruh positif EPS terhadap harga saham(H5)
}

\section{METODE}

Dalam meneliti, cara atau teknik serta metode penting untuk digunakan. Penggunaan metode yang tepat dan sesuai dapat memberi dampak yang baik pada penelitian orang. Apalagi banyak yang harus dilakukan dalam meneliti, seperti pengambilan sampel, cara menganalisis datanya, dan hal lainnya.

Pengambilan sampel saya disini dengan menggunakan kriteria pemilihan sampel. Merupakan mengambil sampel sesuai kriteria serta pedoman dasar yang disusun peneliti untuk menentukan sampel. Selain itu, penyusunannya juga berdasar hal - hal yang dapat mendukung sampel.

Dengan adanya acuan dasar yang sudah disusun, peneliti tidak bisa menggunakan seluruh populasi untuk menjadi sampel dalam penelitiannya. Hanya populasi yang sesuai dengan kriterialah yang dapat dipakai sebagai sampel dalam meneliti.

Adapun kriterianya antara lain:

- Perusahaan Barang Konsumsi terdaftar di BEl sebelum tahun 2013.

- Perusahaan Industri Barang Konsumsi sudah mempublikasikan laporan keuangan tiap akhir tahun, dari tahun 2013 - 2018.

- $\quad$ Industri Barang Konsumsi mendapatkan laba dalam tahun 2013 - 2018. 


\section{Journal of Sustainability Business Research (JSBR) \\ Vol-1,Issue-1,Desember (JSBR) \\ E-ISSN: 2746-8607 \\ http://jurnal.unipasby.ac.id/index.php/jsbr}

Selain ada kriteria yang saya susun, dalam rangka mengumpulkan disini juga ada tata cara atau langkah yang dilalui secara bertahap. Tata cara yang diterapkan guna pengumpulan data ada beberapa seperti :

a. Melakukan pengambilan data untuk perusahaan yang masuk dalam kriteria. Sebelumnya telah dilakukan pemilihan sampel menggunakan data yang telah diunduh di web idx juga di web dari perusahaan.

b. Data Laporan Keuangan yang digunakan hanya tahun 2013 sampai 2018

c. Melakukan pengelolahan data

d. Analisis data menggunakan SPSS (Statstic Program for Social) version (25.0)

e. Membuat simpulan dan saran.

Selain mengumpulkan data, setelah data dikumpulkan ada juga cara untuk analisis data yang sudah didapat, dengan memakai statistik program SPSS(version 25.0). SPSS ini dipakai agar mudah dalam menghitung angka yag ada ketika mencari pengaruh seluruh variabel. Langkah yang dilakukan antara lain :

Uji asumsi klasik, yang terdiri dari :

- Norrmalitas

- Multikolienaritas

- Heteroeskedastisitas

- Autokorealasi

Analisis Regresi Linear Berganda

$>$ Pengujian Hipotesiis, yang terdiri dari:

- Koefisien Determinasi

- Pengujian Signifikan Parsial (Uji t)

HASIL

Hasil atas penelitain telah saya lakukan, terdiri dari hasil tabel uji asumsi klasik, analiss liniear berganda, dan perhitungan koefisien determinasi. Seperti berikut hasil yang saya dapat :

Uji Asumsi Klasik

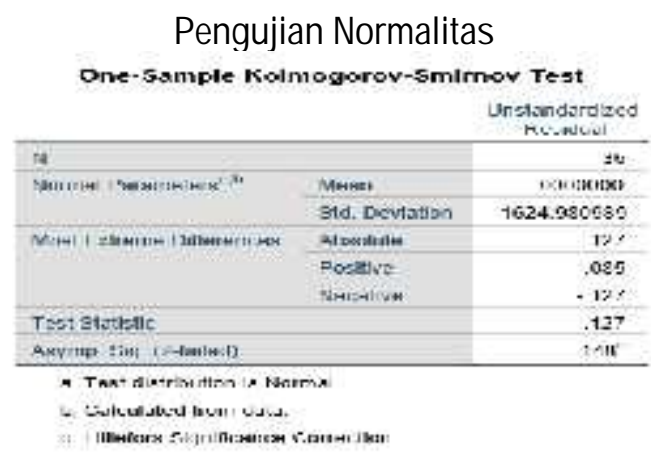

Dari hasil Output SPSS, untuk mengetahui normal tidaknya dapat dilihat dari nilai sig yang ada di paling bawah. Terlihat jelas angka sig sebesar 0,148. Jadi, data yang ada dalam penelitian ini bersifat normal. Normal karena nilainya lebih besar dari 0,05. Jika kurang, maka datanya tidak normal. Sehingga penelitian ini normal.

Uji Multikolinearitas 
Journal of Sustainability Business Research (JSBR)

Vol-1,Issue-1,Desember (JSBR)

E-ISSN: 2746-8607

http://jurnal.unipasby.ac.id/index.php/jsbr

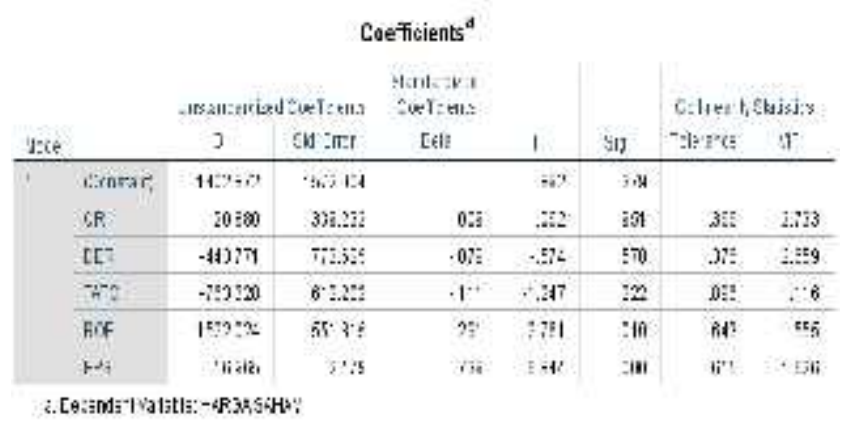

Hasil pengujian yang disajikan pada tabel tersebut dapat diketahui nilai toleransi variabel bebas $\mathrm{CR}$ $(0,366)$, DER $(0,376)$, TATO $(0,896)$, ROE $(0,643)$, dan EPS $(0,615)$. Dari hasil pengujian tersebut tidak ada nilai toleransi pada variabel kurang dari 0,10 . Selain nilai toleransi, dari hasil pengujian tersebut dapat diketahu nilai Variance Inflation Factors (VIF).

VIF harus mempunyai angka tidak lebih dari 10. Pada pengujian ini, angka vif yang ada pada seluruh variabel bebas berangka kurang dari 10 , sehingga pada pengujian ini gejala multikolinieritas tidak ditemukan.

\section{Uji Heteroskedastisitas}

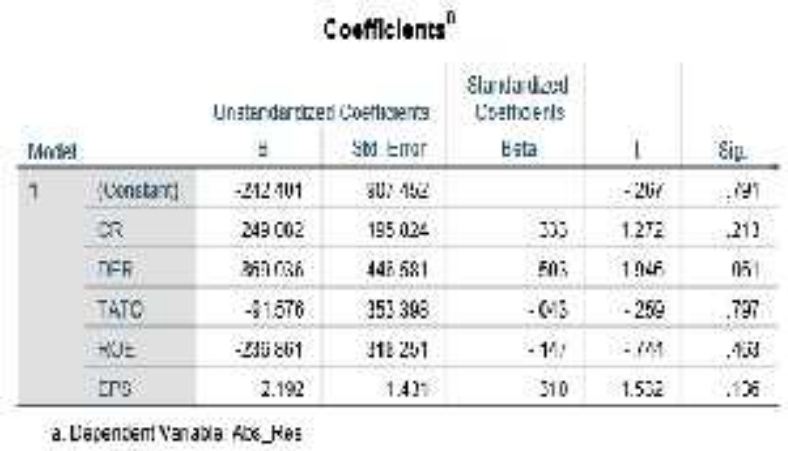

Hasil Uji Heterokedastiditas dapat diketahui dengan melihat angka pada kolom sig pada tabel yang terletak di kolom paling kanan. Nilai signifikan pada semua variabel CR hingga EPS menghasilkan angka lebih dari 0,05 . Sehingga dikatakan bahwa tidak terjadi gejala heteroskedastisitas.

Uji Autokorelasi

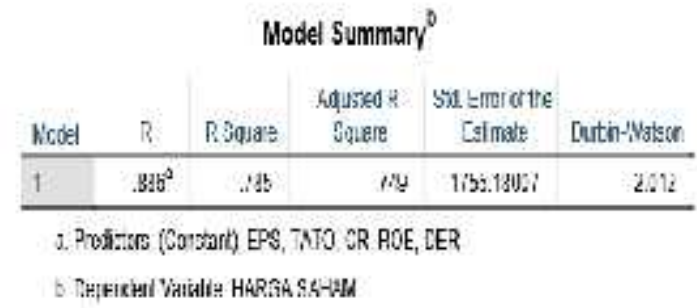

Hasil Uji Autokeralasi, dapat diketahui melalui angka pada kolom Durbin Watson. Terlihat pada kolom di atas bahwa angka Durbin Watson menunjukkan angka sebesar 2,012, sehingga dapat dikatakan tidak ditemukan masalah autokorelasi.

Uji Regresi Liniear Berganda 
Journal of Sustainability Business Research (JSBR)

Vol-1,Issue-1,Desember (JSBR)

E-ISSN: 2746-8607

http://jurnal.unipasby.ac.id/index.php/jsbr

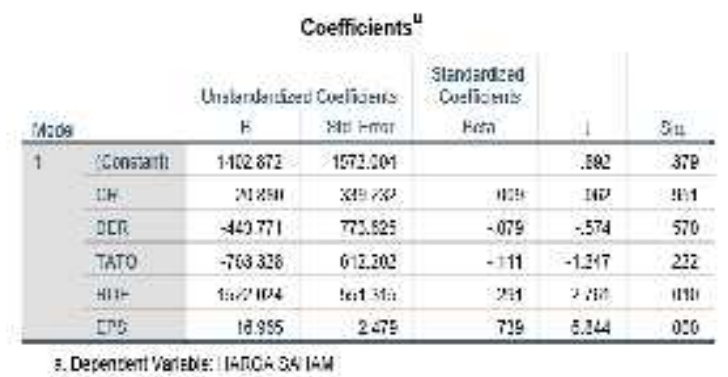

Uji ini dapat dilihat melalui kolom pertama. Angka yang ada menjelaskan pergerakan yan terjadi ketika adanya pengaruh positif atau negatif variabel yang dipakai dengan variabel terikat. Uji ini dapat memberikan persamaan seperti :

Harga Saham $=1402,87+20,88 \mathrm{CR}-443,77$ DER $-763,32$ TATO + 1522,02 ROE + 16,96 EPS +1572

Pengujian Hipotesis

Koefisisen Determinasi

\section{Hasil Perhitungan \\ Koefisien Determinasi}

\begin{tabular}{|c|c|c|c|c|}
\hline \multicolumn{5}{|c|}{ Modol Summary } \\
\hline Nodct & $R$ & R Squar & $\begin{array}{l}\text { idjusted ? } \\
\text { Square }\end{array}$ & $\begin{array}{l}\text { Std. [not of the } \\
\text { Estmalo }\end{array}$ \\
\hline 1 & $\sin ^{2}$ & the & $i<\theta$ & 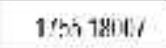 \\
\hline
\end{tabular}

3. Predictors: i,Constanti, EPS, TATO, CR, ROE, DER

Berdasarkan tabel tersebut, dapat diketahui hasil perhitungan koefisien determinasi dengan melihat angka yang ada pada kolom R. Koefisien korelasi (R) di tabel menghasilkan nilai 0,886, sehingga menunjukkan hubungan variabel bebas terhadap variabel terikat secara simultan cukup kuat. Ada juga kolom R Squar $(0,785)$.

\section{Uji T}

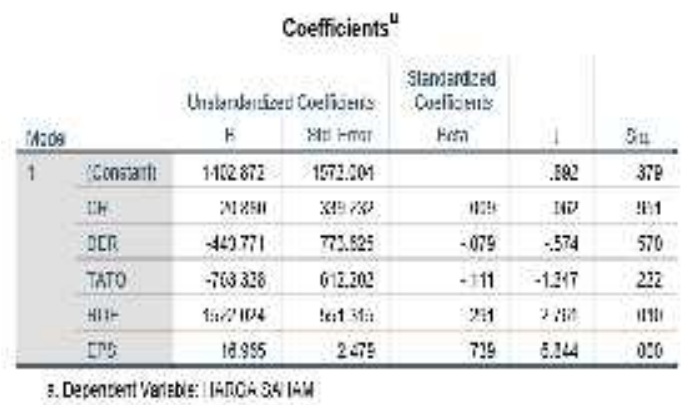

Dari hasil pengujian tersebut, dapat dijelaskan dari 5 variabel bebas hanya ada 2 variabel yang menunjukkan pengaruhnya terhadap harga saham sedangkan variabel lainnya tidak berpengaruh secara signifikan. Dua variabel itu yang memberi pengaruh adalah ROE dan EPS.

\section{SIMPULAN}

Dari hasil penelitian yang sudah saya susun, diperoleh hasil yang signifikan mempengaruhi dan yang tidak mempengaruhi. Sehingga jawaban sementara yang sebelumnya sudah ada, ada dua yang diterima dan tiga yang tidak diterima / ditolak. Disini saya juga dapat menyimpulkan atas hasil yang 


\section{Journal of Sustainability Business Research (JSBR) \\ Vol-1,Issue-1,Desember (JSBR) \\ E-ISSN: 2746-8607 \\ http://jurnal.unipasby.ac.id/index.php/jsbr}

sudah saya peroleh.

CR, DER, dan TATO membuktikan, ketiga variabel tidak mempengaruhi variabel terikat yakni harga saham. CR hanya dijadikan untuk bisa melihat tinggi rendahnya kondisi likuid perusahaan. Sedangkan DER, untuk menegtahui banyaknya pendanaan hutang melalui aktva yang dimilki. Kemudian TATO, hanya dijadikan acuan oleh investor mengetahui kondisi aktiva dan penjualan perusahaan dan tidak untuk penentuan harga saham perusahaan.

ROE dan EPS membuktikan sama - sama dapat mempengaruhi harga saham. ROE, mewakili pemakaian untuk apa modal sendiri pada perusahaan serta menentukan besar kecilnya harga saham yang beredar. Sedangkan EPS, membuat investor lebih merasa puas atas laba di setiap saham sehingga bisa mempengaruhi besar kecilnya harga saham.

\section{IMPLIKASI}

Perusahaan sebaiknya lebih meningkatkan kinerja perusahaan agar setiap tahunnya harga saham perusahaan tetap stabil sehingga para calon investor tertarik untuk berinvestasi. Bagi Investor sebaiknya harus menganalisa dengan baik suiatu perusahaan yang akan dituju untuk menanamkan sahamnya. Terutama mengenai nilai perusahaan yang menggambarkan kinerja sebuah perusahaan. Investor sebaiknya lebih memahami rasio keuangan untuk menilai sebuah perusahaan agar bisa mengetahui kondisi keuangan perusahaan tersebut, sehingga dapat memperkirakan resiko yang akan dihadapi ataupun keuntungan yang diperoleh dalam berinvestasi.

\section{KETERBATASAN PENELITIAN}

Penelitian tidak bisa lepas dari keterbatasan. Dengan adanya keterbatasan, saya merasa bahwa tidak semua hal bisa kita dapatkan dengan cara yang gampang.

Didalam penelitian ini terdapat suatu keterbatasan pada variabel- variabel yang diuji. Pada penelitian ini ada 5 variabel bebas dan 1 variabel terikat. Dari 5 variabel independent tersebut merupakan masing - masing perwakilan dari setiap jenis rasio keuangan. Sehingga bukan merupakan bagian dari satu jenis rasio keuangan saja.

\section{DAFTAR PUSTAKA}

Astuti, Rani. 2017. Analisis Pengaruh Rasio Keuangan Terhadap Harga Saham Pada Perusahaan Manufaktur Sektor Makanan dan Minuman Yang Terdaftar Di Indeks Saham Syariah Indonesia Tahun 2012- 2016. Skripsi, Institut Agama Islam Negeri Surakarta

Kasmir. 2010. Analisis Laporan Keuangan. Jakarta: Rajawali Pers . 2013. Analisis Laporan Keuangan. Jakarta: PT. Raja Grafindo Persada

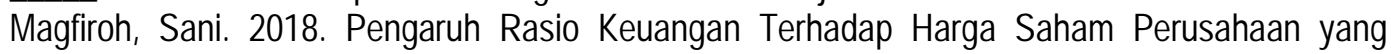
Terdaftar Di Jakarta Islamic Index (JII). Skripsi, Universitas Islam Negeri Ar- Raniry.

Nisa, Haslita. 2018. Pengaruh Rasio Keuangan Terhadap Harga Saham pada Industri Sektor Pertanian yang terdaftar di Bursa Efek Indonesia Tahun 2012 - 2016. Skripsi, Universitas Negeri Yogyakarta.

Putro, Prasetyo Moektiono. 2017. Analisis Pengaruh Rasio Keuangan terhadap harga saham pada perusahaan manufaktur yang terdaftar di BEI.Skripsi.Universitas Muhammadiyah Surakarta.

Saputra, Angga Bayu. 2011. Analisis Pengaruh Rasio Keuangan Terhadap Harga. Skripsi, Universitas Sanata Dharma Yogyakarta.

Sari, Warsani Purnama.2018. Pengaruh Rasio Keuangan Terhadap Harga Saham pada Perusahaan Manufaktur Go Public yang Terdaftar Di Bursa Efek Indonesia. Volume 2, Nomor 1, ISSN: 2614-5154, Yayasan Pengembangan Profesi Sumatra Utara.

Suharno.2016. Pengaruh Rasio Keuangan Terhadap Harga Saham Perusahaan Farmasi yang Terdaftar Di Bursa Efek Indonesia Tahun 2010 - 2014. Skripsi, Universitas Negeri Yogyakarta.

Tandellin, Eduardus. 2007. Analisis Investasi dan Manajemen Portofolio. Yogyakarta: BPFE Yogyakarta.

Widayanti, Rita dan Colline, Fredella. 2017. Pengaruh Rasio Keuangan Terhadap Harga Saham

Perusahaan LQ 45 Periode 2011-2015. Volume 21, Nomor 1, Universitas Kristen Krida Wacana 
Journal of Sustainability Business Research (JSBR)

Vol-1,Issue-1,Desember (JSBR)

E-ISSN: 2746-8607

http://jurnal.unipasby.ac.id/index.php/jsbr 